\title{
Nitrogen Addition Enhances Drought Sensitivity of Young Deciduous Tree Species
}

\author{
Christoph Dziedek ${ }^{1}$, Werner Härdtle ${ }^{1}$, Goddert von Oheimb ${ }^{2}$ and Andreas Fichtner ${ }^{1 *}$ \\ 1 Institute of Ecology, Leuphana University of Lüneburg, Lüneburg, Germany, ${ }^{2}$ Institute of General Ecology and \\ Environmental Protection, Dresden University of Technology, Tharandt, Germany
}

\section{OPEN ACCESS}

Edited by:

Sebastian Leuzinger,

Auckland University of Technology,

New Zealand

Reviewed by:

Rebekka Bögelein,

University of Trier, Germany

Rodica Pena

University of Göttingen, Germany

*Correspondence:

Andreas Fichtner

fichtner@leuphana.de

Specialty section:

This article was submitted to Functional Plant Ecology,

a section of the journal

Frontiers in Plant Science

Received: 04 May 2016

Accepted: 11 July 2016

Published: 22 July 2016

Citation:

Dziedek C, Härdtle W, von Oheimb G and Fichtner A (2016) Nitrogen Addition Enhances Drought Sensitivity of Young Deciduous Tree Species. Front. Plant Sci. 7:1100. doi: 10.3389/fpls.2016.01100
Understanding how trees respond to global change drivers is central to predict changes in forest structure and functions. Although there is evidence on the mode of nitrogen $(\mathrm{N})$ and drought $(\mathrm{D})$ effects on tree growth, our understanding of the interplay of these factors is still limited. Simultaneously, as mixtures are expected to be less sensitive to global change as compared to monocultures, we aimed to investigate the combined effects of $\mathrm{N}$ addition and $\mathrm{D}$ on the productivity of three tree species (Fagus sylvatica, Quercus petraea, Pseudotsuga menziesii) in relation to functional diverse species mixtures using data from a 4-year field experiment in Northwest Germany. Here we show that species mixing can mitigate the negative effects of combined $\mathrm{N}$ fertilization and $\mathrm{D}$ events, but the community response is mainly driven by the combination of certain traits rather than the tree species richness of a community. For beech, we found that negative effects of $\mathrm{D}$ on growth rates were amplified by $\mathrm{N}$ fertilization (i.e., combined treatment effects were non-additive), while for oak and fir, the simultaneous effects of $\mathrm{N}$ and $\mathrm{D}$ were additive. Beech and oak were identified as most sensitive to combined $\mathrm{N}+\mathrm{D}$ effects with a strong size-dependency observed for beech, suggesting that the negative impact of $\mathrm{N}+\mathrm{D}$ becomes stronger with time as beech grows larger. As a consequence, the net biodiversity effect declined at the community level, which can be mainly assigned to a distinct loss of complementarity in beech-oak mixtures. This pattern, however, was not evident in the other species-mixtures, indicating that neighborhood composition (i.e., trait combination), but not tree species richness mediated the relationship between tree diversity and treatment effects on tree growth. Our findings point to the importance of the qualitative role ('trait portfolio') that biodiversity play in determining resistance of diverse tree communities to environmental changes. As such, they provide further understanding for adaptive management strategies in the context of global change.

Keywords: climate change, complementarity, ecosystem functioning, insurance hypothesis, nitrogen deposition, plant-climate interactions, temperate forest, tree growth

\section{INTRODUCTION}

Forest ecosystems are currently facing unprecedented shifts in environmental conditions, with implications for biodiversity patterns, ecosystem functions and services (Anderson-Teixeira et al., 2015). Important drivers of environmental shifts are, among others, climate change and atmospheric changes, for example the deposition of reactive forms of nitrogen (Vitousek et al., 1997; Sala et al., 2000). Climate change, accompanied by increasing temperatures and more 
frequent drought events (IPCC, 2013), is expected to severely affect carbon and water cycles of forest ecosystems (Grossiord et al., 2014). Moreover, drought events and increasing summer temperatures may impose constraints on growth and competitiveness of trees species that are considered sensitive to water shortage (Geßler et al., 2007; Grossiord et al., 2014). On the other hand, atmospheric deposition of nitrogen (N) has tripled since 1860 and is expected to further increase in coming decades (Galloway et al., 2004). In forest ecosystems, $\mathrm{N}$ deposition is considered responsible for accelerated biomass increment in recent decades, because tree growth is often limited by the availability of $\mathrm{N}$ (Rennenberg et al., 1998; Nadelhoffer, 2000; Pretzsch et al., 2014). Long-term N loading has also been shown to alter soil nutrient cycling and promote soil acidification, leaching of nitrate and soil cations (Magill et al., 1997; Aber et al., 1998; Rennenberg et al., 1998). Consequently, both an increase in nitrogen deposition and drought events may have severe consequences for forest community dynamics, and thus for ecosystem functioning and services.

Due to the global importance of forest ecosystems, there is a bulk of research that addressed the effects of global change drivers on various ecosystem functions (for a global overview see Allen et al., 2010; Bobbink et al., 2010). Many studies, however, have focused on single-factor approaches, whereas analyses on interaction effects are scarce (Zavaleta et al., 2003; Yang et al., 2013), particularly for combined $\mathrm{N}$ and D effects (Nilsen, 1995; Meyer-Grünefeldt et al., 2015b,a). It is conceivable, for example, that co-occurring drivers of global change do not act additively (i.e., the summation of single effects), but have non-additive effects on ecosystem responses (i.e., show antagonistic or synergistic interactions; Meyer-Grünefeldt et al., 2015b). This implies that ecosystem responses to multiple environmental shifts cannot be inferred from single-factor studies alone, and emphasizes the need for concomitant multi-factor approaches (Lindenmayer et al., 2010; Ochoa-Hueso et al., 2014; Hautier et al., 2014).

Next to the physiological response of individual trees, the structure and composition of forest ecosystems is central for allowing forest to adapt to global environmental changes (Coomes et al., 2014; De Frenne et al., 2015). In this context, species diversity is assumed to mitigate climate change effects on forest productivity, because diverse forests are expected to react less sensitively to environmental shifts as compared to monocultures (Filotas et al., 2014). Overall, there is increasing evidence that biodiversity promotes various ecosystem functions and services (e.g., Cardinale et al., 2012), and three main mechanisms have been proved to drive diversity-functioning relationships: complementarity (i.e., resource partitioning and facilitation), selection (or sampling) effects (i.e., the higher likelihood that mixtures contain highly productive species) and ecological insurance (Loreau and Hector, 2001; Scherer-Lorenzen, 2014). Many recent biodiversityecosystem functioning experiments provided evidence that increasing diversity can reduce the variability of ecosystem properties, and thus increase the temporal stability (e.g., in terms of resistance or resilience) at the ecosystem level (Tilman et al., 2006; Hector et al., 2010; Proulx et al., 2010; Isbell et al., 2015). For instance, observational and simulational studies have shown a positive relationship between tree species richness and the stability of wood production (Jucker et al., 2014; Morin et al., 2014). This beneficial stabilizing effect of biodiversity, also termed as 'insurance hypothesis' (Yachi and Loreau, 1999), can arise from overyielding (i.e., the productivity of mixtures is higher than the average of the monocultures or most productive monoculture), the spatial (i.e., niche partitioning), or temporal (i.e., species asynchrony) complementarity between species or facilitative plant-interactions (Loreau, 2010; Hector et al., 2010; McIntire and Fajardo, 2014). Thus, biodiversity related 'insurance effects' imply that diverse forests are composed of tree species that (i) differ with regard to intrinsic responses to environmental change, (ii) differ with regard to the speed with which they respond to environmental disturbances, or (iii) show a reduction in the strength of competition (Loreau and de Mazancourt, 2013).

We evaluated how $\mathrm{N}$ addition and drought interactively affect tree growth in monocultures and mixtures. In a 4-year field experiment with juvenile trees, in which we altered species combinations and species richness levels, we exposed monocultures and mixtures to full-factorial combinations of summer drought and $\mathrm{N}$ fertilization. Experiments were conducted with three different tree species: European beech (Fagus sylvatica), Sessile oak (Quercus petraea), and Douglas fir (Pseudotsuga menziesii), henceforth referred to as beech, oak, and fir, respectively. These species differ in key functional traits that are linked to productivity and shade tolerance (e.g., specific leaf area, leaf longevity, and wood density) and are considered to be ecologically and/or economically important from a European perspective (Valladares and Niinemets, 2008; Ellenberg and Leuschner, 2010; Lasky et al., 2014). Specifically, we asked, how sole and combined effects of $\mathrm{N}$ fertilization and drought mediate (i) tree-level growth in relation to species identity (of the target and neighboring trees), (ii) stand-level growth in relation to species combination and richness, and (iii) complementarity and selection effects and thus net biodiversity effects of tree communities.

\section{MATERIALS AND METHODS}

\section{Study Area}

All experimental sites were established in near-natural broadleaved forest ecosystems typical of the lowlands of NW Germany (Lower Saxony, $53^{\circ} 8^{\prime} 7.827^{\prime \prime} \mathrm{N} 10^{\circ} 22^{\prime} 20.96^{\prime \prime}$ ). Soils of the study area developed from sediments of the penultimate glacial period, and prevailing soil types are acidic Cambisols or Luvisols (according to the WRB system, 2006). Mean $\mathrm{pH}_{\mathrm{H} 2 \mathrm{O}}$-values in the upper mineral $(\mathrm{A}-$ ) horizon ranged between 3.9 and 4.7. The natural forest communities at these sites are acidic beech forests that belong to the Galio odorati-Fagetum (Ellenberg and Leuschner, 2010). The climate is of a sub-oceanic type. Mean precipitation is $718 \mathrm{~mm} \mathrm{yr}^{-1}$, and the annual mean temperature is $9.2^{\circ} \mathrm{C}$. 


\section{Experimental Design and Plant Material}

In April 2010 we established a 4-year field experiment using a randomized block design (with seven replicate blocks). Blocks were established under larger canopy gaps (0.250.50 ha in size) to simulate a quasi-natural regeneration situation under an opened canopy. All blocks were fenced during the experiment to exclude grazing effects. Each block consisted of six plots with different species combinations, where three target species (beech, oak, and fir) were grown, either in monoculture, 2-species or 3-species mixtures (for species combinations see Table 1). Each plot was divided into four subplots $(1 \mathrm{~m} \times 1 \mathrm{~m})$ with $0.5 \mathrm{~m}$ wide buffer strips, and each subplot was randomly assigned to one of the following treatments: control, nitrogen $(\mathrm{N})$ fertilization, drought treatment, and a combination of $\mathrm{N}$ fertilization and drought treatment (henceforth referred to as control, $\mathrm{N}$ treatment, $\mathrm{D}$ treatment, and $\mathrm{N}+\mathrm{D}$ treatment, respectively). The experiment thus comprised six species combinations and four treatment levels, resulting in a total of 24 experimental combinations (each $7 \times$ replicated).

In April 2010, each subplot was planted with 25 3year-old tree saplings (planting distance: $20 \mathrm{~cm}$ ), which originated from a local forest nursery. In mixed-species subplots, trees were planted in a systematic species alteration pattern (e.g., beech-oak-fir-beech-oak-fir etc.). To account for edge effects, only the central nine individuals were considered as target trees for subsequent analyses. All treatments started in the year 2012, i.e., 2 years after sapling planting. This delayed start was chosen to avoid confounding effects between experimental treatments and planting.

In the $\mathrm{N}$ treatments (i.e., $\mathrm{N}$ and $\mathrm{N}+\mathrm{D}$ ), $\mathrm{N}$ was applied (as $\mathrm{NH}_{4} \mathrm{NO}_{3}$ ) in a quantity equivalent to $50 \mathrm{~kg} \mathrm{~N} \mathrm{ha}^{-1} \mathrm{yr}^{-1}$ (as solution in deionized water). This treatment strength was chosen to simulate the effects of atmospheric $\mathrm{N}$ deposition which some forest ecosystems currently receive in NW Europe (with $50 \mathrm{~kg}$ $\mathrm{N} \mathrm{ha}{ }^{-1} \mathrm{yr}^{-1}$ representing the upper range limit of current deposition rates; Galloway et al., 2004; Bobbink et al., 2010).

TABLE 1 | Design of the experiment.

\begin{tabular}{llll}
\hline Species & $\begin{array}{l}\text { Diversity } \\
\text { level }\end{array}$ & $\begin{array}{l}\text { Species } \\
\text { combination }\end{array}$ & No. trees \\
\hline Fagus sylvatica (beech) & mono & - & 252 \\
Quercus petraea (oak) & mono & - & 252 \\
Pseudotsuga menziesii (fir) & mono & - & 252 \\
Fagus sylvatica & mix2 & beech-oak & 140 \\
Fagus sylvatica & mix2 & beech-fir & 140 \\
Quercus petraea & mix2 & beech-oak & 112 \\
Pseudotsuga menziesii & mix2 & beech-fir & 112 \\
Fagus sylvatica & mix3 & beech-oak-fir & 84 \\
Quercus petraea & mix3 & beech-oak-fir & 84 \\
Pseudotsuga menziesii & mix3 & beech-oak-fir & 84 \\
\hline Total & & & 1512
\end{tabular}

Number of planted target trees of each diversity level and species combination. Mono, monoculture; mix2, 2-species mixture; mix3, 3-species mixture.
To simulate summer drought events (D treatments; i.e., $\mathrm{D}$ and $\mathrm{N}+\mathrm{D}$ ) we installed rain-out shelters (2-3 $\mathrm{m}$ aboveground) with UV transparent foil (UV-B Window, folitec $\mathrm{GmbH}$, Westerburg, Germany) in the respective subplots to exclude any precipitation. The rain-out shelters were installed from July 9th to July 31st and August 13th to September 7th in 2012, and from July 5th to September 5th in 2013. Effects of $\mathrm{D}$ treatments on soil water contents were determined by means of volumetric soil water content sensors (based on Time Domain Reflectometry; Decagon Devices, Pullman, WA, USA) that were installed in four representative blocks in 2012 and 2013 in the upper mineral soil $(0-5 \mathrm{~cm})$. Measurements of volumetric soil water contents indicated that D treatments reduced the soil water content by about $20 \%$ (volumetric losses compared to field capacity, achieved during the last week of the D treatments), which corresponds to a moderate-severe drought event in the study region (Rose et al., 2009).

\section{Tree Measurements}

For all trees, height and biomass were determined. Tree height (measured from the root collar to the top) was recorded at the beginning of the treatment application (April 2012) and at the end of the experiment in September 2013, which corresponded to a 2-year growing period. For each tree we calculated relative growth rate (RGR) of tree height as $\mathrm{RGR}=\left(\ln \mathrm{H}_{2}-\ln \right.$ $\left.\mathrm{H}_{1}\right) /\left(\mathrm{t}_{2}-\mathrm{t}_{1}\right)$, where $\mathrm{H}_{1}$ and $\mathrm{H}_{2}$ are the tree heights at the beginning $\left(t_{1}\right)$ and end $\left(t_{2}\right)$ of the experiment. We used RGR instead of absolute growth rates as a response variable to model individual tree growth, because RGR is less sensitive toward differences in initial size (Mencuccini et al., 2005). After tree harvest (September 2013), we additionally measured the stem biomass (including branches) and the biomass of leaves or needles for all tree individuals. Biomass samples were dried at $40^{\circ} \mathrm{C}$ for 3 days (until weight constancy) and

TABLE 2 | Target tree characteristics of the three study species.

\begin{tabular}{|c|c|c|}
\hline & Mean $(S D)$ & Range \\
\hline \multicolumn{3}{|l|}{ Fagus sylvatica } \\
\hline Initial tree height $(\mathrm{cm})$ & $89.4(16.5)$ & $52.0-141.0$ \\
\hline AGB $(g)$ & $51.5(41.4)$ & $4.5-305.1$ \\
\hline AGR $\left(\mathrm{cm}\right.$ year $\left.^{-1}\right)$ & $16.7(11.4)$ & $0.0-55.5$ \\
\hline $\operatorname{RGR}\left(\mathrm{cm} \mathrm{cm}^{-1}\right.$ year $\left.^{-1}\right)$ & $0.15(0.08)$ & $0.0-0.37$ \\
\hline \multicolumn{3}{|l|}{ Quercus petraea } \\
\hline Initial tree height (cm) & $101.0(25.2)$ & $38.0-178.0$ \\
\hline AGB $(g)$ & $53.0(48.3)$ & $0.1-323.8$ \\
\hline AGR $\left(\mathrm{cm}\right.$ year $\left.{ }^{-1}\right)$ & $17.2(12.3)$ & $0.0-59.0$ \\
\hline $\operatorname{RGR}\left(\mathrm{cm} \mathrm{cm}^{-1}\right.$ year $\left.^{-1}\right)$ & $0.13(0.08)$ & $0.0-0.36$ \\
\hline \multicolumn{3}{|l|}{ Pseudotsuga menziesii } \\
\hline Initial tree height $(\mathrm{cm})$ & $118.6(25.9)$ & $62.0-202.0$ \\
\hline AGB $(g)$ & $150.3(107.7)$ & $16.2-683.2$ \\
\hline AGR $\left(\mathrm{cm}\right.$ year $\left.^{-1}\right)$ & $28.6(13.7)$ & $0.0-87.0$ \\
\hline $\operatorname{RGR}\left(\mathrm{cm} \mathrm{cm}^{-1}\right.$ year $\left.^{-1}\right)$ & $0.19(0.07)$ & $0.0-0.37$ \\
\hline
\end{tabular}

Absolute (AGR) and relative growth rate (RGR) of tree height refer to a 2-year census interval; $A G B$, aboveground biomass at the end of the census interval. 
subsequently weighted. Target tree characteristics are provided in Table 2.

\section{Data Analysis}

Individual tree growth analyses was focused on 1291 target trees in total (beech: 558, oak: 320 , fir: 413). Due to mortality, $12 \%$ of the original 1512 target trees were not available to be measured at the end of the experiment. Oak showed highest mortality, followed by fir and beech, but we found no statistically significant treatment effect across species (beech: $P=0.10$; oak: $P=0.91$; fir: $P=0.83$; Supplementary Figure S1). Moreover, observations with negative growth rates (3\% of the surviving trees) were assumed to be damage-related (e.g., due to planting failures or falling large-sized branches) or to have measurement error, and therefore omitted in the subsequent height growth analysis to avoid biased estimates. However, trees with zero increments were retained.

To examine the tree size, treatment, and species diversity (measured as species richness) dependence of RGR of the three target species, we applied linear mixed models using block, plot and treatment as nested random factors. We fitted several alternative models for each target species separately including initial height, treatment, species combination, and their interactions as fixed effects. To address the skewed response and heteroscedasticity of the beech and oak growth data, the residual error was modeled using a variance function based on the power of the fitted values (Pinheiro and Bates, 2004). Models were selected based on the Akaike Information Criterion (AIC) and maximum likelihood (ML) estimations. Moreover, we ranked the models based on Akaike weights $\left(w_{i}\right)$, which are the relative likelihood of each model to be the best-fitting model, given the complete set of candidate models (Burnham and Anderson, 2002). Only models with an AIC difference $(\triangle \mathrm{AIC}) \leq 2$ (compared with the best-fitting model) were considered as models with substantial support (Burnham and Anderson, 2002), and for each species the model with the highest Akaike weights was chosen as the most parsimonious model. Parameter estimates of the bestfitting models were based on the restricted maximum likelihood (REML) method.

The strength of each treatment effect on RGR rates was determined by the magnitude of treatment effect (MTE). MTE was calculated as MTE $=\left(\mathrm{X}_{\mathrm{T}}-\mathrm{X}_{\mathrm{C}}\right) /\left(\mathrm{X}_{\mathrm{T}}+\mathrm{X}_{\mathrm{C}}\right)$, where $\mathrm{X}_{\mathrm{T}}$ is the predicted response of target tree $i$ in the global change driver treatments $(\mathrm{N}, \mathrm{D}, \mathrm{N}+\mathrm{D})$ and $\mathrm{X}_{\mathrm{C}}$ the predicted response in the control (C) treatment. This index ranges from -1 (negative global change driver influence) to +1 (positive global change driver influence) for each species, thus facilitating between-species comparisons. Differences in MTE among species were evaluated by analysis of variance (ANOVA) with a post hoc performance (Tukey HSD test).

Total aboveground biomass (all woody compartments and leaves; AGB) was used as a response for tree vigor. For trees that died during the experiment we used the average speciesspecific AGB of each treatment and species combination. We applied the additive partitioning method according to Loreau and Hector (2001) to quantify the net biodiversity effect (NE) on
AGB of species mixtures, which we further partitioned into the complementarity (CE), and selection effect (SE). NE, CE, and SE were calculated using the following equations:

$$
\begin{aligned}
\mathrm{NE} & =\Sigma \mathrm{Y}-\overline{\mathrm{M}} \\
\mathrm{CE} & =\mathrm{N} \times \overline{\mathrm{M}} \times \overline{\Delta \mathrm{RY}} \\
\mathrm{SE} & =\mathrm{N} \times \operatorname{cov}(\mathrm{M}, \Delta \mathrm{RY})
\end{aligned}
$$

where $\mathrm{Y}$ is the observed AGB for each species in mixture and $\mathrm{M}$ is the yield of a species growing in monoculture. $\mathrm{N}$ is the number of species and $\Delta \mathrm{RY}$ the deviation from the expected relative yield of a species in mixture $(\Delta \mathrm{RY}=(\mathrm{Y} / \mathrm{M})-(1 / \mathrm{N}))$.

To account for size differences of the species-mixtures, and thus allow for inter-site comparisons, diversity components were standardized dividing NE, CE, and SE by the expected AGB based on monocultures (see Morin et al., 2011). For the subsequent analysis these values were square-root transformed to meet the model assumptions while preserving the original positive and negative signs (Loreau and Hector, 2001). For each species combination we fitted a linear-mixed effects model using treatment as fixed effect and block as random factor to account for potential differences in site conditions. All statistical analyses were performed in $\mathrm{R}$ (version 3.1.0 $)$ using the packages nlme and MuMIn.

\section{RESULTS}

\section{Effects of Nitrogen Fertilization and Drought on Tree-Level Height Growth}

For all species the minimum adequate models according to the AIC included tree size, treatment and species composition effects (Table 3). For beech, the treatment effects significantly depended on tree size $(P<0.01$; Table 4$)$, with treatment effects becoming more pronounced with increasing height. For oak and fir, the RGR-treatment relationships were consistent across the observed height range. Compared to control plots, RGR of oak was significantly lower in the $\mathrm{N}+\mathrm{D}$ treatment $(P<0.05)$, and marginally significant lower in the $\mathrm{N}$ treatment $(P \leq 0.1)$, while a significant decline in RGR of fir was induced by drought $(P<0.05)$. Moreover, a significant species composition effect on the shape of the size response was observed for beech $(P<0.001)$ and oak $(P<0.01)$, while for fir, the species composition effect $(P<0.01)$ was independent of tree size (Table 4$)$. There was no support for a statistically significant three-way interaction effect on RGR, showing that for each species the size-treatment relationship did not shift with species composition (Table 3). Graphical validation plots indicated unbiased estimates. The best-supported models explained between $41 \%$ (beech), $44 \%$ (oak), and $51 \%$ (fir) of the variation in RGR of height.

The positive RGR-size relationship was most pronounced for beech with a greater increase in growth rates when growing in mixture with fir (Figure 1). Similarly, RGR of oak trees in monoculture increased with size. In contrast, the influence of

\footnotetext{
${ }^{1}$ http://www.R-project.org
} 


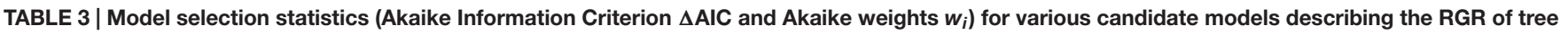
height as a function of initial tree height $(\mathrm{H})$, treatment $(\mathrm{T})$, and species composition (C) effects of European beech (Fagus sylvatica), Sessile oak (Quercus petraea), and Douglas fir (Pseudotsuga menziesii).

\begin{tabular}{|c|c|c|c|c|c|c|c|c|c|c|c|c|c|}
\hline \multirow[t]{2}{*}{ Model } & \multicolumn{7}{|c|}{ Fixed effects } & \multicolumn{2}{|c|}{ Fagus sylvatica } & \multicolumn{2}{|c|}{ Quercus petraea } & \multicolumn{2}{|c|}{ Pseudotsuga menziesii } \\
\hline & $\mathbf{H}$ & $\mathbf{T}$ & C & $\mathbf{H} \times \mathbf{T}$ & $\mathrm{H} \times \mathbf{C}$ & $\mathbf{T} \times \mathbf{C}$ & $H \times T \times C$ & $\Delta \mathrm{AIC}$ & $w_{i}$ & $\Delta \mathrm{AIC}$ & $w_{i}$ & $\Delta \mathrm{AIC}$ & $w_{i}$ \\
\hline 1 & $x$ & $x$ & & & & & & 23.99 & 0.00 & 4.47 & 0.08 & 11.57 & 0.00 \\
\hline 2 & $\times$ & & $\times$ & & & & & 15.72 & 0.00 & 7.94 & 0.01 & 2.38 & 0.09 \\
\hline 3 & & $x$ & $\times$ & & & & & 73.76 & 0.00 & 9.46 & 0.01 & 7.21 & 0.01 \\
\hline 4 & $\times$ & $x$ & $x$ & & & & & 19.45 & 0.00 & 7.25 & 0.02 & 0.01 & 0.30 \\
\hline 5 & $\times$ & $\times$ & $\times$ & $\times$ & & & & 13.67 & 0.00 & 10.08 & 0.00 & 0.00 & 0.30 \\
\hline 6 & $x$ & $x$ & $x$ & & $x$ & & & 10.82 & 0.00 & 0.13 & 0.50 & 1.20 & 0.16 \\
\hline 7 & $\times$ & $\times$ & $\times$ & & & $\times$ & & 25.29 & 0.00 & 8.32 & 0.01 & 7.38 & 0.01 \\
\hline 8 & $x$ & $\times$ & $\times$ & $\times$ & $x$ & & & 0.00 & 0.91 & 3.51 & 0.07 & 1.75 & 0.12 \\
\hline 9 & $x$ & $\times$ & $\times$ & $x$ & & $\times$ & & 19.64 & 0.00 & 8.55 & 0.00 & 7.81 & 0.01 \\
\hline 10 & $x$ & $x$ & $x$ & & $\times$ & $x$ & & 14.00 & 0.00 & 0.00 & 0.26 & 8.42 & 0.00 \\
\hline 11 & $\times$ & $\times$ & $\times$ & $\times$ & $\times$ & $x$ & & 4.74 & 0.08 & 2.55 & 0.05 & 9.46 & 0.00 \\
\hline 12 & $x$ & $\times$ & $\times$ & $\times$ & $\times$ & $\times$ & $x$ & 15.61 & 0.00 & 5.20 & 0.00 & 15.21 & 0.00 \\
\hline
\end{tabular}

The best-supported models with the highest Akaike weights are highlighted in bold. For Douglas fir the more parsimonious model that included a marginal significant height-treatment interaction $(P=0.09)$ was rejected, since the main effects-only model fit the data equally well $\left(\Delta \mathrm{AlC}=0.01, w_{\mathrm{i}}\right.$ for both models $\left.=30 \%\right)$.

size was less evident for oak growing in 2- or 3-species mixtures and fir growing either in monoculture or mixture. The mode of growth response to treatment effects, however, was significantly different among species and tree sizes (Figure 2). Oak and fir showed an additive response (summation of the single effects) to simultaneous $\mathrm{N}$ addition and drought, whereas the response of beech was non-additive (i.e., an antagonistic response of smaller and a synergistic response of larger individuals). This trend was consistent along the investigated diversity gradient, since we did not observe interacting effects of treatment and species composition (Table 3).

Compared to the control, RGR of small trees in the $\mathrm{N}$ treatment was lower for beech and oak, but higher for fir (Figure 2).

TABLE 4 | Best-fitting mixed-effects models for RGR of tree height of (a) European beech (Fagus sylvatica), (b) Sessile oak (Quercus petraea) and (c) Douglas fir (Pseudotsuga menziesii).

\begin{tabular}{|c|c|c|c|}
\hline Fixed effects & d.f. & L-ratio & $P$-value \\
\hline \multicolumn{4}{|l|}{ (a) Fagus sylvatica } \\
\hline Initial tree height $(\mathrm{H})$ & 1 & 56.3 & $<0.001$ \\
\hline Treatment $(T)$ & 3 & 2.3 & 0.517 \\
\hline Species composition (C) & 3 & 10.5 & 0.014 \\
\hline $\mathrm{H} \times \mathrm{T}$ & 3 & 15.3 & 0.002 \\
\hline $\mathrm{H} \times \mathrm{C}$ & 3 & 20.9 & $<0.001$ \\
\hline \multicolumn{4}{|l|}{ (b) Quercus petraea } \\
\hline Initial tree height $(\mathrm{H})$ & 1 & 4.2 & 0.040 \\
\hline Treatment $(\mathrm{T})$ & 3 & 6.7 & 0.082 \\
\hline Species composition (C) & 2 & 1.2 & 0.543 \\
\hline $\mathrm{H} \times \mathrm{C}$ & 2 & 10.0 & 0.007 \\
\hline \multicolumn{4}{|l|}{ (c) Pseudotsuga menziesii } \\
\hline Initial tree height $(H)$ & 1 & 15.6 & $<0.001$ \\
\hline Treatment $(T)$ & 3 & 8.4 & 0.039 \\
\hline Species composition (C) & 2 & 9.2 & 0.002 \\
\hline
\end{tabular}

In contrast to oak, growth rates of large beech and fir trees were enhanced by nitrogen enrichment $\left(P_{\mathrm{adj}}\right.$. $\left.<0.01\right)$. In contrast, drought reduced height growth of all species and sizes with effects being strongest for large-sized beech trees $\left(P_{\text {adj. }}<0.001\right)$. The combination of $\mathrm{N}$ addition and drought was negative for all species, but size-dependency was strongest for beech. The sensitivity of oak and fir to $\mathrm{N}+\mathrm{D}$ was equally high for small and large trees, with effects being much stronger for oak. Large beech trees, however, suffered most from $\mathrm{N}+\mathrm{D}$, resulting in a sevenfold decline in growth rates compared to small individuals. Thus, growth reductions induced by combined $\mathrm{N}$ and $\mathrm{D}$ effects of large individuals significantly increased within the series fir $<$ oak $<$ beech (all comparisons: $P_{\text {adj. }}<0.05$; Figure 2).

AGB was closely related to RGR, and the strength of the relationship did not significantly differ among species (Supplementary Figure S2).

\section{Effects of Nitrogen Fertilization and Drought on Stand-Level Biomass Production}

In the absence of $\mathrm{D}$ or $\mathrm{N}$ treatments the mixture effect on overall stand productivity was positive for all species mixtures (Figure 3). Overyielding was evident in $81 \%$ of the control plots and in 69\% of the sites (blocks) across treatments (Supplementary Table S1), but we observed a large variation across sites (Supplementary Table S2).

The impact of global change drivers (D, N, or $\mathrm{N}+\mathrm{D}$ ) on the net biodiversity effect was driven by species identity rather than species diversity. Regardless of treatment, the average net diversity effects of beech-fir and beech-oak-fir stands remained positive and did not statistically differ from the control (Figure 3). In contrast, for beech-oak mixtures the magnitude and direction of diversity effects differed between treatments. $\mathrm{N}$ addition reduced the positive effect of species mixture to become 

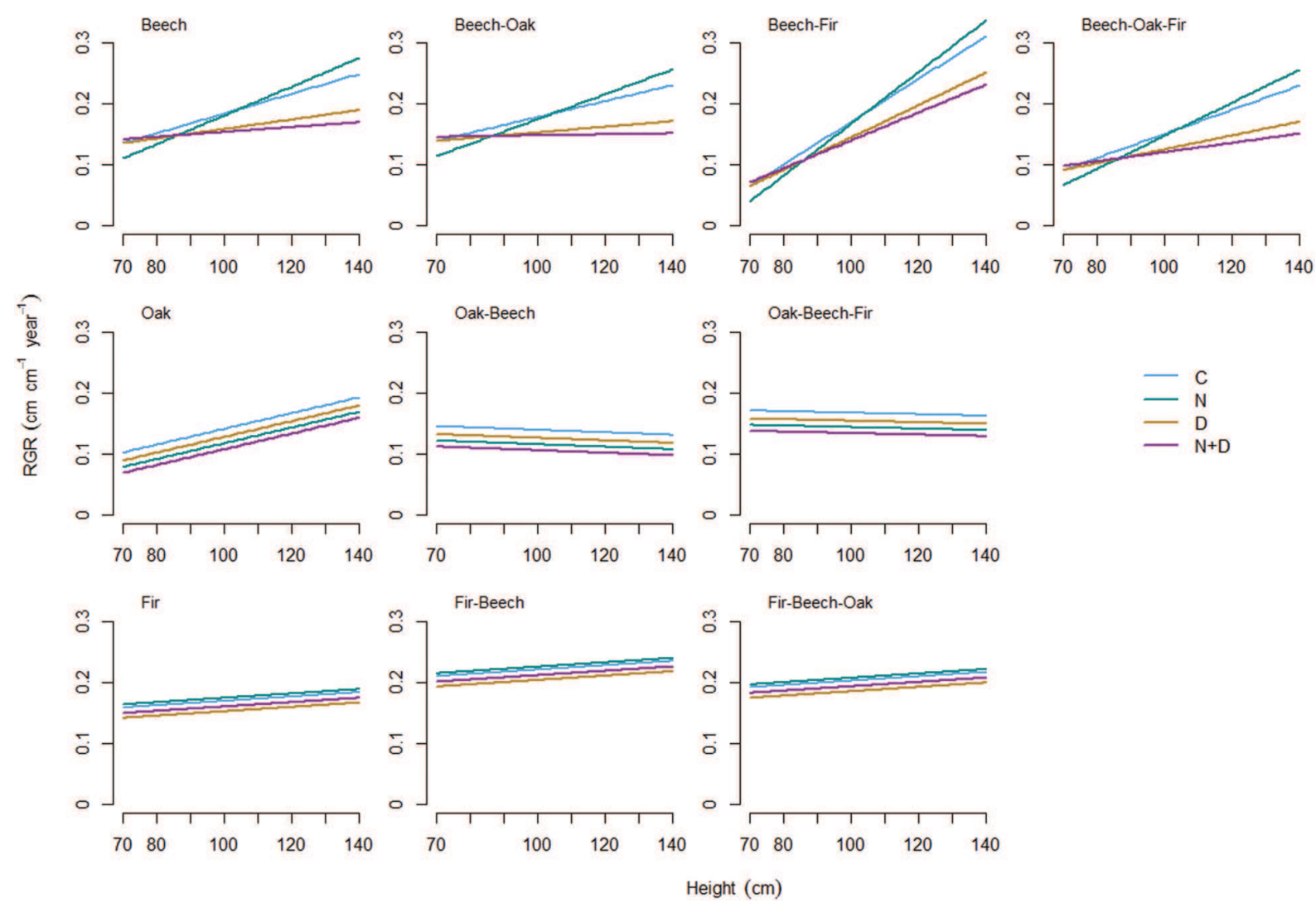

FIGURE 1 | Relationship between tree size (initial height), global change effects (C, control; N, nitrogen addition; D, drought; N+D: nitrogen addition plus drought), species diversity (monoculture; 2-species mixture, and 3-species mixture) and relative growth rate (RGR) of tree height for European beech (Fagus sylvatica; upper row), Sessile oak (Quercus petraea; middle row) and Douglas fir (Pseudotsuga menziesii; lower row). Regression lines are based on the predictions of the best-fitted models in Table 4.

neutral $(P=0.1)$, whereas the combined effects of $\mathrm{N}$ addition and drought caused a significant loss of biodiversity effects and underyielding, respectively $(P<0.05$; Figure 3$)$. This pattern can be primarily attributed to the loss of complementarity effects with regard to the $\mathrm{N}+\mathrm{D}$ treatment $(P<0.05)$ and selection effects in relation to the $\mathrm{N}$ treatment $(P<0.1)$. Similarly, different underlying complementarity and selection effects were obvious for beech-fir and beech-oak-fir mixtures. In $61 \%$ of the beech-fir sites the selection effect was greater than the complementarity effect, particularly in the D treatment. Thus, high stand biomass productivities can be mainly ascribed to fir. In the 3-species mixture the selection effect became negative in the $\mathrm{N}+\mathrm{D}$ treatment $(P=0.1)$ and neutral in the $\mathrm{N}$ treatment, but CE were always greater than SE (Figure 3).

\section{DISCUSSION}

\section{Species-Specific Growth Response to Combined Effects of Nitrogen Addition and Drought}

Our results show that tree growth response to treatments was mainly driven by species identity rather than species diversity, and the combined effects of $\mathrm{N}$ and $\mathrm{D}$ treatments proved to be both additive and non-additive. In the first case, the combined effects of $\mathrm{N}+\mathrm{D}$ on RGR of tree height corresponded with the sum of the single effects (oak and fir), but in the latter case the combination of both factors caused negative growth responses, with mutually amplifying effects (for large beech trees, despite the positive single effect of $\mathrm{N}$ fertilization). This finding suggests that - at least in the case of beech - growth responses to environmental shifts are difficult to infer from species responses to single factors (Zavaleta et al., 2003). Several mechanisms may account for the non-additive effects of $\mathrm{N}+\mathrm{D}$ treatments. First, $\mathrm{N}$ fertilization often results in a shift in biomass allocation patterns (in favor of aboveground biomass), resulting in a concomitant increase of biomass shoot-root ratios (Thomas and Hilker, 2000; Meyer-Grünefeldt et al., 2015b). For example, leave biomass investments of coniferous tree species increased with $\mathrm{N}$ fertilization (Högberg et al., 1993), and can thus increase the water consumption and probability of water stress (Nilsen, 1995). The responses described above are in agreement with the 'resource optimization hypothesis', according to which plants show (relatively) higher aboveground investments (and hence higher shoot-root ratios) with increasing nutrient availability 

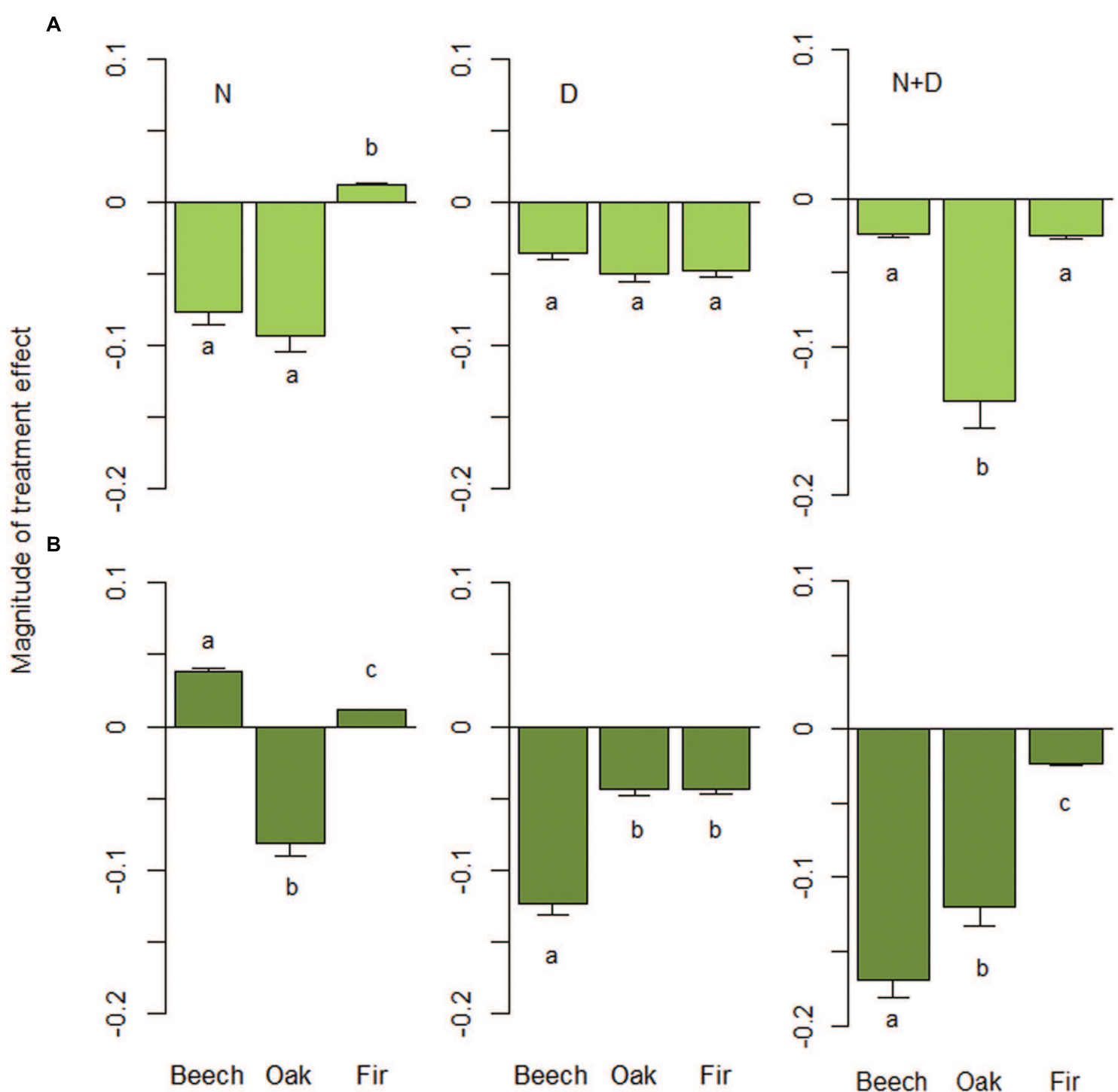

Beech Oak Fir

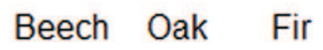

FIGURE 2 | Magnitude of treatment effect (MTE) for nitrogen addition (N), drought (D) and their combination (N+D). For each species (European beech: Fagus sylvatica, Sessile oak: Quercus petraea, and Douglas fir: Pseudotsuga menziesii), MTEs were predicted for (A) small-sized (initial height of $80 \mathrm{~cm}$ ) and (B) large-sized trees (initial height of $130 \mathrm{~cm}$ ) based on our best-fitting models (see Table 4). Error bars show standard errors based on across-species combination response. Different letters indicate significant differences (Tukey-test: $P<0.05$ ) among species.

(McConnaughay and Coleman, 1999; Ågren and Franklin, 2003). High shoot-root ratios, in turn, can lead to increasing evaporative demands and thus a higher sensitivity to drought events (Meyer-Grünefeldt et al., 2015b). Second, N fertilization can increase fine- and coarse-root mortality and decrease the mycorrhiza colonization, both of which can impair supply and therefore increase their drought sensitivity (Hendricks et al., 2000; Nadelhoffer, 2000; Teste et al., 2012). Third, as trees can optimize the fine root and branch hydraulic system in water-limited environments (Hertel et al., 2013; Schuldt et al., 2016), an increasing $\mathrm{N}$ availability might prevent such adaptation mechanisms and therefore increase the suspectibility to drougth.
Tree species also responded differently to $\mathrm{N}$ fertilization, with a facilitation of (large) beech and fir trees, but adverse effects on oak. Deleterious effects of $\mathrm{N}$ fertilization on juvenile oak trees have also been reported in the study of BassiriRad et al. (2015), without a clear indication of the underlying mechanisms. In our study, species-specific responses are likely related to their traits and competitive hierarchy. Oak trees are light-demanding and may suffer from an unfavorable light environment when overgrown from larger neighbors, particularly at $\mathrm{N}$-fertilized sites (Ellenberg and Leuschner, 2010). In this context, the strong size-asymmetry of treatment effects for beech suggests that our findings are related to size-asymmetric competition, because larger individuals mostly obtain a disproportionate share of 


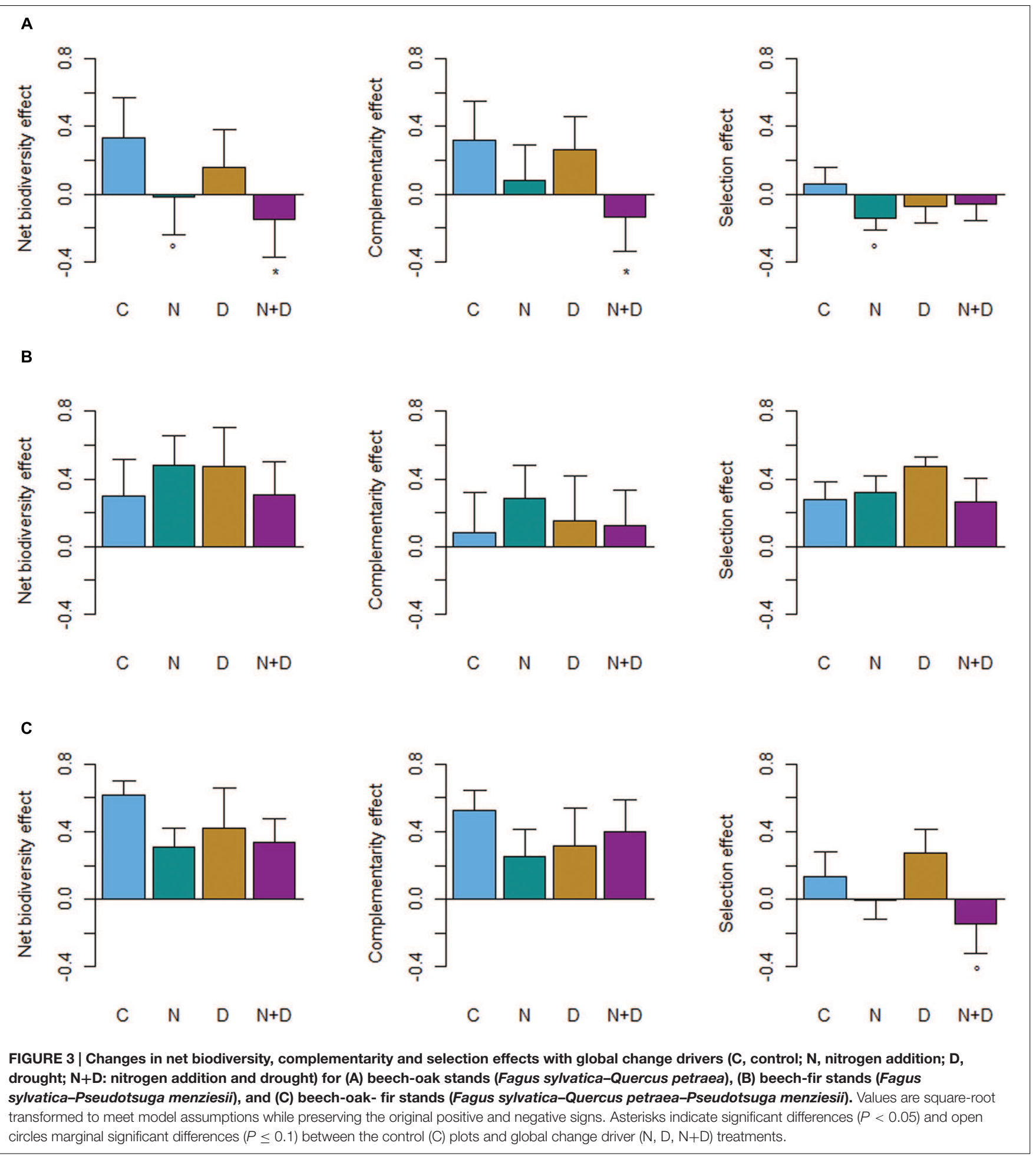

resources and thus suppress the growth of smaller individuals (Potvin and Dutilleul, 2009). As a consequence, larger trees have a competitive advantage in resource acquisition over smaller individuals, and thus benefit most from additional nutrients, explaining the $\mathrm{N}$-induced height growth decline of smaller oak and beech trees.
Species differences in the sensitivity to drought, as shown for larger individuals in our study, coincides with the wellknown ecophysiology of these species (see for example Thomas, 2000; Geßler et al., 2007; Meier and Leuschner, 2008; Friedrichs et al., 2009; Härdtle et al., 2014). In a study of five temperate adult tree species, Zimmermann et al. (2015) found that beech 
is most susceptible to drought, which is in line with our observed increasing drought sensitivity as beech trees grew larger. Thus, species-specific differences in drought sensitivity might result in shifts in the competitive hierarchy in mixed-species tree communities. Our study, however, provided no evidence for changes of treatment effects depending on community composition. This suggests that treatment effects at the scale of individual trees were highly species-specific, and growth responses of juvenile trees to treatments were strongly mediated by the species' trait characteristics (also see discussion below) and local neigborhood conditions (Lübbe et al., 2015, 2016). An additional explanation to the statistically non-significant threeway interaction $(\mathrm{H} \times \mathrm{T} \times \mathrm{C})$ and two-way interaction $(\mathrm{T} \times \mathrm{C})$ is that diversity effects may need time to fully evolve in long-living plant communities such as forests, and therefore may become more pronounced as trees become larger.

We found that tree size-related changes in RGR were contextspecific (neighborhood composition) and varied with species identity. Species interactions leading to a spatial complementarity in resource use due to differences in leaf habit (e.g., Coomes et al., 2009) are likely to be important in beech-fir mixtures. As a result, species mixing can mitigate drought susceptibility of mature beech trees by reducing intra-specific competition (Metz et al., 2016). In contrast, oak trees (as the most lightdemanding species) proved to be week competitors (at least under the given experimental settings), and benefitted most from growing with conspecific neighbors. Thus, positive mixture effects in our study may be primarily the result of trait induced competitive hierarchies (Kunstler et al., 2012) and the species' trait characteristics also accounted for the observed interacting effects of tree size and species composition.

\section{Functional Composition of Forests Modulate the Effects of Nitrogen Addition and Drought on Stand Productivity}

Overyielding was evident for almost all plots across treatments, which is in agreement with many previous studies reporting a positive effect of tree diversity on forest productivity (e.g., Paquette and Messier, 2011; Vilà et al., 2013; Forrester and Bauhus, 2016). However, in our experiment the NE on stand-level productivity strongly depended on both the species composition and the species-specific responses to treatments. In the beechoak mixture, we found a significant underyielding in the N+D treatment, attributable to negative $\mathrm{N}+\mathrm{D}$ effects on $\mathrm{CE}$. We hypothesize that the negative NE was brought about by the negative responses of beech and oak to $\mathrm{N}+\mathrm{D}$ treatments already observed at the tree-level. This, in turn, would indicate that stand-level, and tree-level responses to 'environmental shifts' are closely related, or, more specifically, may depend on the trait characteristics of the species included in a mixture (Lübbe et al., 2015). This interpretation is supported by the result that we found no NE and a negative SE for beech-oak mixtures in the $\mathrm{N}$ treatment, likely brought about by the strong negative response of oak trees to $\mathrm{N}$ fertilization. We conclude that the resistance of a species mixture to environmental shifts may be more determined by the traits typical of the species included in a mixture than by the mere complementarity of the traits (or the functional dissimilarity) of these species (as given in the case of beech and oak). Biodiversity thus would not serve per se as an 'insurance' for the mitigation of global change effects on ecosystem functions (Lübbe et al., 2015), but would act in terms of a 'trait portfolio' that preserves a broad spectrum of functional traits enabling a species' resistance to environmental stressor (comparable to a lock-and-key model, according to which only particular traits ensure higher resistance of plant communities to environmental shifts; Polley et al., 2013). This perspective emphasizes the importance of both the quantity and quality of biodiversity for ecosystem resistance to environmental change (Mouillot et al., 2013).

The hypothesis provided above also supports the interpretation of treatment responses of those mixtures in which fir was included (i.e., beech-fir and beech-oak-fir mixtures). In these mixtures we found positive NE across treatments, suggesting that fir acted as a kind of 'buffer' mitigating the (partly negative) effects of $\mathrm{N}$ fertilization and drought. In the beech-fir mixture, positive NE were mainly attributable to SE, particularly in the D treatment. Obviously, the low sensitivity of fir to $\mathrm{D}$ and $\mathrm{N}+\mathrm{D}$ treatments (of small and small + large trees, respectively; see Bansal et al., 2015) was conveyed to the stand-level, resulting in the observed positive $\mathrm{NE}$ across treatments. In the 3-species mixture, fir obviously mitigated the adverse effects of $\mathrm{N}$ and $\mathrm{N}+\mathrm{D}$ observed for the beech-oak mixture, resulting in positive $\mathrm{CE}$ (substantially contributing to the NE). We hypothesize that trait-characteristics of fir mainly concurred to the observed response pattern (e.g., its low drought sensitivity; Bansal et al., 2015), resulting in an increased stand-level resistance of the tree-mixture. In summary, stand-level responses to treatments (and corresponding NE) were strongly mediated by species composition and the species' functional trait characteristics included in a mixture. This finding is in line with our observation on the individual tree level and matches observations in other tree diversity experiments, according to which species identity often proved to be as influential as species richness effects on productivity patterns (Jacob et al., 2010; Lang et al., 2012; Grossiord et al., 2013; Ratcliffe et al., 2015).

\section{CONCLUSION}

Our results highlight the importance of assessing interacting effects of nitrogen addition and drought to evaluate forest productivity in response to global environmental change. We are aware of the limitation to generalize results from juvenile tree field-experiments to adult tree communities, but manipulations of $\mathrm{N}$ and $\mathrm{D}$ treatments are hardly achievable in later forest development stages due to the longevity of trees. Hence, our experimental framework provides a unique opportunity to enhance our mechanistic understanding of tree growth in the context of global change by disentangling the effects of various global change drivers and their interactions unequivocally.

We found evidence that the magnitude and direction of combined global change driver effects depend on species identity 
and neighborhood composition (i.e., trait combination) rather than the level of tree species richness. Thus, species diversity might not mitigate per se the impact of drought and increasing $\mathrm{N}$ deposition in long-living plant communities. Instead, the occurrence of certain trait combinations ('trait portfolio') in diverse communities might act as an 'insurance' for the mitigation of global change effects on ecosystem functions. This suggests that the quality of trait composition ('lock-and-key principle') is a main component of the ecological insurance hypothesis.

\section{AUTHOR CONTRIBUTIONS}

WH and GvO conceived the study. CD performed the field and laboratory work, and AF analyzed the data. $\mathrm{AF}, \mathrm{CD}, \mathrm{WH}$, and $\mathrm{GvO}$ wrote the manuscript.

\section{REFERENCES}

Aber, J., McDowell, W., Nadelhoffer, K., Magill, A., Berntson, G., Kamakea, M., et al. (1998). Nitrogen saturation in temperate forest ecosystems. Bioscience 48, 921-934. doi: 10.1007/978-94-017-2789-1_13

Ågren, G. I., and Franklin, O. (2003). Root:shoot ratios, optimization and nitrogen productivity. Ann. Bot. 92, 795-800. doi: 10.1093/aob/mcg203

Allen, C. D., Macalady, A. K., Chenchouni, H., Bachelet, D., McDowell, N., Vennetier, M., et al. (2010). A global overview of drought and heat-induced tree mortality reveals emerging climate change risks for forests. For. Ecol. Manage. 259, 660-684. doi: 10.1016/j.foreco.2009.09.001

Anderson-Teixeira, K. J., Davies, S. J., Bennett, A. C., Gonzalez-Akre, E. B., MullerLandau, H. C., Wright, S. J., et al. (2015). CTFS-ForestGEO: a worldwide network monitoring forests in an era of global change. Glob. Change Biol. 21, 528-549. doi: 10.1111/gcb.12712

Bansal, S., Harrington, C. A., Gould, P. J., and St. Clair, J. B. (2015). Climate-related genetic variation in drought-resistance of Douglas-fir (Pseudotsuga menziesii). Glob. Change Biol. 21, 947-958. doi: 10.1111/gcb.12719

BassiriRad, H., Lussenhop, J. F., Sehtiya, H. L., and Borden, K. K. (2015). Nitrogen deposition potentially contributes to oak regeneration failure in the Midwestern temperate forests of the USA. Oecologia 177, 53-63. doi: 10.1007/s00442-0143119-z

Bobbink, R., Hicks, K., Galloway, J., Spranger, T., Alkemade, R., Ashmore, M., et al. (2010). Global assessment of nitrogen deposition effects on terrestrial plant diversity: a synthesis. Ecol. Appl. 20, 30-59. doi: 10.1890/081140.1

Burnham, K. P., and Anderson, D. R. (2002). Model Selection and Multimodel Inference: A Practical Information-Theoretical Approach. New York, NY: Springer.

Cardinale, B. J., Duffy, J. E., Gonzalez, A., Hooper, D. U., Perrings, C., Venail, P., et al. (2012). Biodiversity loss and its impact on humanity. Nature 486, 59-67. doi: 10.1038/nature11148

Coomes, D. A., Flores, O., Holdaway, R., Jucker, T., Lines, E. R., and Vanderwel, M. C. (2014). Wood production response to climate change will depend critically on forest composition and structure. Glob. Chance Biol. 20, 3632-3645. doi: $10.1111 /$ gcb.12622

Coomes, D. A., Kunstler, G., Canham, C. D., and Wright, E. (2009). A greater range of shade-tolerance niches in nutrient-rich forests: an explanation for positive richness-productivity relationships? J. Ecol. 97, 705-717. doi: 10.1111/j.13652745.2009.01507.x

De Frenne, P., Rodríguez-Sánchez, F., De Schrijver, A., Coomes, D. A., Hermy, M., Vangansbeke, P., et al. (2015). Light accelerates plant responses to warming. Nat. Plants 1, 15110. doi: 10.1038/nplants. 2015.110

Ellenberg, H., and Leuschner, C. (2010). Vegetation Mitteleuropas mit den Alpen. Stuttgart: Ulmer.

\section{FUNDING}

The study was supported by the Friedrich-Ebert Foundation, Bonn.

\section{ACKNOWLEDGMENTS}

We thank KH Meyer for the provision of the experimental site and his assistance during the experiment. We are grateful for the support of the forestry department Oerrel (Lower-Saxony).

\section{SUPPLEMENTARY MATERIAL}

The Supplementary Material for this article can be found online at: http://journal.frontiersin.org/article/10.3389/fpls.2016.01100

Filotas, E., Parrot, L., Burton, P. J., Chazdon, R. L., Coates, K. D., Coll, L., et al. (2014). Viewing forests through the lens of complex systems science. Ecosphere 5, 1-23. doi: 10.1890/ES13-00182.1

Forrester, D. I., and Bauhus, J. (2016). A review of processes behind diversity-productivity relationships in forests. Curr. For. Rep. 2, 45-61. doi: 10.1007/s40725-016-0031-2

Friedrichs, D. A., Trouet, V., Büntgen, U., Frank, D. C., Esper, J., Neuwirth, B., et al. (2009). Species-specific climate sensitivity of tree growth in Central-West Germany. Trees 23, 729-739. doi: 10.1007/s00468-009-0315-2

Galloway, J. N., Dentener, F. J., Capone, D. G., Boyer, E. W., Howarth, R. W., Seitzinger, S. P., et al. (2004). Nitrogen cycles: past, present, and future. Biogeochemistry 70, 153-226. doi: 10.1007/s10533-0040370-0

Geßler, A., Keitel, C., Kreuzwieser, J., Matyssek, R., Seiler, W., and Renneberg, H. (2007). Potential risks for European beech (Fagus sylvatica L.) in a changing climate. Trees 21, 1-11. doi: 10.1007/s00468-006-0107-x

Grossiord, C., Granier, A., Geßler, A., Pollastrini, M., and Bonal, D. (2013). The influence of tree species mixture on ecosystem-level carbon accumulation and water use in a mixed boreal plantation. For. Ecol. Manage. 298, 82-92. doi: 10.1016/j.foreco.2013.03.001

Grossiord, C., Granier, A., Ratcliffe, S., Bouriaud, O., Bruelheide, H., Checko, E., et al. (2014). Tree diversity does not always improve resistance of forest ecosystems to drought. Proc. Natl. Acad. Sci. U.S.A. 111, 14812-14815. doi: 10.1073/pnas.1411970111

Härdtle, W., Niemeyer, T., Fichtner, A., Li, Y., Ries, C., Schuldt, A., et al. (2014). Climate imprints on tree-ring $\delta 15 \mathrm{~N}$ signatures of sessile oak (Quercus petraea Liebl.) on soils with contrasting water availability. Ecol. Indic. 45, 45-50. doi: 10.1016/j.ecolind.2014.03.015

Hautier, Y., Seabloom, E. W., Borer, E. T., Adler, P. B., Harpole, S., Hillebrand, H., et al. (2014). Eutrophication weakens stabilizing effects of diversity in natural grasslands. Nature 508, 521-525. doi: 10.1038/nature13014

Hector, A., Hautier, Y., Saner, P., Wacker, L., Bagchi, R., Joshi, J., et al. (2010). General stabilizing effects of plant diversity on grassland productivity through population asynchrony and overyielding. Ecology 91, 2213-2220. doi: 10.1890/09-1162.1

Hendricks, J. J., Aber, J. D., Nadelhoffer, K. J., and Hallett, R. D. (2000). Nitrogen controls on fine root substrate quality in temperate forest ecosystems. Ecosystems 3, 57-69. doi: 10.1007/s100210000010

Hertel, D., Strecker, T., Müuller-Haubold, H., and Leuschner, C. (2013). Fine root biomass and dynamics in beech forests across a precipitation gradient - is optimal resource partitioning theory applicable to waterlimited mature trees? J. Ecol. 101, 1183-1200. doi: 10.1111/1365-2745. 12124

Högberg, P., Johannisson, C., and Hallgren, J. E. (1993). Studies of 13C in the foliage reveal interactions between nutrients and water in forest fertilization experiments. Plant Soil 152, 207-214. doi: 10.1007/BF00029090 
IPCC (2013). Climate Change 2013: The Physical Science Basis. Contribution of Working Group $i$ to the Fifth Assessment Report of the Intergovernmental Panel on Climate Change. Cambridge, MA: Cambridge University Press.

Isbell, F., Craven, D., Connolly, J., Loreau, M., Schmid, B., Beierkuhnlein, C., et al. (2015). Biodiversity increases the resistance of ecosystem productivity to climate extremes. Nature 526, 574-577. doi: 10.1038/nature15374

Jacob, M., Leuschner, C., and Thomas, F. M. (2010). Productivity of temperate broad-leaved forest stands differing in tree species diversity. Ann. For. Sci. 67:503. doi: $10.1051 /$ forest/2010005

Jucker, T., Bouriaud, O., Avacaritei, D., and Coomes, D. A. (2014). Stabilizing effects of diversity on aboveground wood production in forest ecosystems: linking patterns and processes. Ecol. Lett. 17, 1560-1569. doi: 10.1111/ele.12382

Kunstler, G., Lavergne, S., Courbaud, B., Thuiller, W., Vieilledent, G., Zimmermann, N. E., et al. (2012). Competitive interactions between forest trees are driven by species' trait hierarchy, not phylogenetic or functional similarity: implications for forest community assembly. Ecol. Lett. 15, 831-840. doi: 10.1111/j.1461-0248.2012.01803.x

Lang, A. C., Härdtle, W., Baruffol, M., Böhnke, M., Bruelheide, H., Schmid, B., et al. (2012). Mechanisms promoting tree species coexistence: experimental evidence with saplings of subtropical forest ecosystems of China. J. Veg. Sci. 23, 837-846. doi: $10.1111 / j .1654-1103.2012 .01403 . x$

Lasky, J. R., Uriarte, M., Boukilic, V. K., and Chazdonc, R. L. (2014). Traitmediated assembly processes predict successional changes in community diversity of tropical forests. Proc. Natl. Acad. Sci. U.S.A. 111, 5616-5621. doi: 10.1073/pnas.1319342111

Lindenmayer, D. B., Likens, G. E., Krebs, C. J., and Hobbs, R. J. (2010). Improved probability of detection of ecological "surprises." Proc. Natl. Acad. Sci. U.S.A. 107, 21957-21962. doi: 10.1073/pnas.1015696107

Loreau, M. (2010). From Populations to Ecosystems: Theoretical Foundations For a New Ecological Synthesis. Princeton: Princeton University Press.

Loreau, M., and de Mazancourt, C. (2013). Biodiversity and ecosystem stability: a synthesis of underlying mechanisms. Ecol. Lett. 16, 106-115. doi: 10.1111/ele. 12073

Loreau, M., and Hector, A. (2001). Partitioning selection and complementarity in biodiversity experiments. Nature 412, 72-76. doi: 10.1038/35083573

Lübbe, T., Schuldt, B., Coners, H., and Leuschner, C. (2016). Species diversity and identity effects on the water consumption of tree sapling assemblages under ample and limited water supply. Oikos 125, 86-97. doi: 10.1111/oik.02367

Lübbe, T., Schuldt, B., and Leuschner, C. (2015). Species identity and neighbor size surpass the impact of tree species diversity on productivity in experimental broad-leaved tree sapling assemblages under dry and moist conditions. Front. Plant Sci. 6:857. doi: 10.3389/fpls.2015.00857

Magill, H., Aber, J. D., Hendricks, J. J., Bowden, R. D., Melillo, J. M., and Steudler, P. A. (1997). Biogeochemical response of forest ecosystems to simulated chronic nitrogen deposition. Ecol. Appl. 7, 402-415. doi: 10.1890/10510761(1997)007[0402:BROFET]2.0.CO;2

McConnaughay, K. D. M., and Coleman, J. S. (1999). Biomass allocation in plants: ontogeny or optimality? A test along three resource gradients. Ecology 80, 2581-2593. doi: 10.1890/0012-9658(1999)080[2581:BAIPOO]2.0.CO;2

McIntire, E. J. B., and Fajardo, A. (2014). Facilitation as a ubiquitous driver for biodiversity. New Phytol. 201, 403-416. doi: 10.1111/nph.12478

Meier, I. C., and Leuschner, C. (2008). Leaf size and leaf area index in Fagus sylvatica forests: competing effects of precipitation, temperature, and nitrogen availability. Ecosystems 11, 655-669. doi: 10.1007/s10021-008-9135-2

Mencuccini, M., Martínez-Vilalta, J., Vanderklein, D., Hamid, H. A., Korakaki, E., Lee, S., et al. (2005). Size-mediated ageing reduces vigour in trees. Ecol. Lett. 8, 1183-1190. doi: 10.1111/j.1461-0248.2005.00819.x

Metz, J., Annighöfer, P., Schall, P., Zimmermann, J., Kahl, T., Schulze, E.-D., et al. (2016). Site-adapted admixed tree species reduce drought susceptibility of mature European beech. Glob. Chance Biol. 22, 903-920. doi: 10.1111/gcb.13113

Meyer-Grünefeldt, M., Calvo, L., Marcos, E., von Oheimb, G., and Härdtle, W. (2015a). Impacts of drought and nitrogen addition on Calluna heathlands differ with plant life-history stage. J. Ecol. 103, 1141-1152. doi: 10.1111/13652745.12446

Meyer-Grünefeldt, M., Friedrich, U., Klotz, M., von Oheimb, G., and Härdtle, W. (2015b). Nitrogen deposition and drought events have non-additive effects on plant growth - evidence from greenhouse experiments. Plant Biosyst. 149, 424-432. doi: 10.1080/11263504.2013.853699
Morin, X., Fahse, L., de Mazancourt, C., Scherer-Lorenzen, M., and Bugmann, H. (2014). Temporal stability in forest productivity increases with tree diversity due to asynchrony in species dynamics. Ecol. Lett. 17, 1526-1535. doi: 10.1111/ele.12357

Morin, X., Fahse, L., Scherer-Lorenzen, M., and Bugmann, H. (2011). Tree species richness promotes productivity in temperate forests through strong complementarity between species. Ecol. Lett. 14, 1211-1219. doi: 10.1111/j.1461-0248.2011.01691.x

Mouillot, D., Bellwood, D. R., Baraloto, C., Chave, J., Galzin, R., Harmelin-Vivien, M., et al. (2013). Rare species support vulnerable functions in high-diversity ecosystems. PLoS Biol. 11:e1001569. doi: 10.1371/journal.pbio.1001569

Nadelhoffer, K. J. (2000). The potential effects of nitrogen deposition on fine-root production in forest ecosystems. New Phytol. 147, 131-139. doi: 10.1046/j.14698137.2000.00677.x

Nilsen, P. (1995). Effect of nitrogen on drought strain and nutrient uptake in Norway spruce Picea abies (L.) Karst.) trees. Plant Soil 172, 73-85.

Ochoa-Hueso, R., Bell, M. D., and Manrique, E. (2014). Impacts of increased nitrogen deposition and altered precipitation regimes on soil fertility and functioning in semiarid Mediterranean shrublands. J. Arid Environ. 104, 106115. doi: 10.1016/j.jaridenv.2014.01.020

Paquette, A., and Messier, C. (2011). The effect of biodiversity on tree productivity: from temperate to boreal forests. Glob. Ecol. Biogeogr. 20, 170-180. doi: 10.1111/j.1466-8238.2010.00592.x

Pinheiro, J. C., and Bates, D. M. (2004). Mixed-effects Models in S and S-Plus. New York, NY: Springer.

Polley, H. W., Isbell, F. I., and Wilsey, B. J. (2013). Plant functional traits improve diversity-based predictions of temporal stability of grassland productivity. Oikos 122, 1275-1282. doi: 10.1111/j.1600-0706.2013.00338.x

Potvin, C., and Dutilleul, P. (2009). Neighborhood effects and size-asymmetric competition in a tree plantation varying in diversity. Ecology 90, 321-327. doi: 10.1890/08-0353.1

Pretzsch, H., Biber, P., Schütze, G., Uhl, E., and Rötzer, T. (2014). Forest stand growth dynamics in Central Europe have accelerated since 1870. Nat. Commun. 5:4967. doi: $10.1038 /$ ncomms5967

Proulx, R., Wirth, C., Voigt, W., Weigelt, A., Roscher, C., Attinger, S., et al. (2010). Diversity promotes temporal stability across levels of ecosystem organization in experimental grasslands. PLoS ONE 5:e13382. doi: 10.1371/journal.pone.0013382

Ratcliffe, S., Holzwarth, F., Nadrowski, K., Levick, S., and Wirth, C. (2015). Tree neighbourhood matters - Tree species composition drives diversityproductivity patterns in a near-natural beech forest. For. Ecol. Manage. 335, 225-234. doi: 10.1016/j.foreco.2014.09.032

Rennenberg, H., Kreutzer, K., Papen, H., and Weber, P. (1998). Consequences of high loads of nitrogen for spruce (Picea abies) and beech (Fagus sylvatica) forests. New Phytol. 139, 71-86. doi: 10.1046/j.1469-8137.1998. 00181.x

Rose, L., Leuschner, C., Köckemann, B., and Buschmann, H. (2009). Are marginal beech (Fagus sylvatica L.) provenances a source for drought tolerant ecotypes? Eur. J. Forest Res. 128, 335-343. doi: 10.1007/s10342-009-0268-4

Sala, O. E., Chapin, F. S. III, Armesto, J. J., Berlow, E., Bloomfield, J., Dirzo, R., et al. (2000). Global biodiversity scenarios for the year 2100. Science 287, 1770-1774. doi: $10.1126 /$ scince.287.5459.1770

Scherer-Lorenzen, M. (2014). "The functional role of biodiversity in the context of global change," in Forests and Global Change, eds D. A. Coomes, D. Burslem, and W. Simonson (Cambridge: Cambridge University Press), 195-237.

Schuldt, B., Knutzen, F., Delzon, S., Jansen, S., Müller-Haubold, H., Burlett, R., et al. (2016). How adaptable is the hydraulic system of European beech in the face of climate change-related precipitation reduction? New Phytol. 210, 443-458. doi: 10.1111/nph.13798

Teste, F. P., Lieffers, V. J., and Strelkov, S. E. (2012). Ectomycorrhizal community responses to intensive forest management: thinning alters impact of fertilization. Plant Soil 360, 333-347. doi: 10.1007/s11104-012-1231-6

Thomas, F. M. (2000). Growth and water relations of four deciduous tree species (Fagus sylvatica L., Quercus petraea [MATT.] LIEBL., Q-pubescens WILLD., Sorbus aria [L.] CR.) occurring at Central-European tree-line sites on shallow calcareous soils: physiological reactions of seedlings to severe drought. Flora 195, 104-115. 
Thomas, F. M., and Hilker, C. (2000). Nitrate reduction in leaves and roots of young pedunculate oaks (Quercus robur) growing on different nitrate concentrations. Environ. Exp. Bot. 43, 19-32. doi: 10.1016/S0098-8472(99)00040-4

Tilman, D., Reich, P. B., and Knops, J. M. H. (2006). Biodiversity and ecosystem stability in a decade-long grassland experiment. Nature 441, 629-632. doi: 10.1038 /nature04742

Valladares, F., and Niinemets, Ü. (2008). Shade tolerance, a key plant feature of complex nature and consequences. Annu. Rev. Ecol. Evol. Syst. 39, 237-57. doi: 10.1146/annurev.ecolsys.39.110707.173506

Vilà, M., Carrillo-Gavilán, A., Vayreda, J., Bugmann, H., Fridman, J., Grodzki, W., et al. (2013). Disentangling biodiversity and climatic determinants of wood production. PLOS ONE 8:e53530. doi: 10.1371/journal.pone. 0053530

Vitousek, P. M., Mooney, H. A., Lubchenco, J., and Metillo, J. M. (1997). Human domination of earth's ecosystems. Science 277, 494-499. doi: 10.1126/science.277.5325.494

Yachi, S., and Loreau, M. (1999). Biodiversity and ecosystem productivity in a fluctuating environment: the insurance hypothesis. Proc. Natl. Acad. Sci. U.S.A. 96, 1463-1468. doi: 10.1073/pnas.96.4.1463

Yang, Y., Wang, G., Yang, L., and Guo, J. (2013). Effects of drought and warming on biomass, nutrient allocation, and oxidative stress in Abies fabri in Eastern
Tibetan Plateau. J. Plant Growth Regul. 32, 298-306. doi: 10.1007/s00344-0129298-0

Zavaleta, E. S., Shaw, M. R., Chiariello, N. R., Mooney, H. A., and Field, C. B. (2003). Additive effects of simulated climate changes, elevated $\mathrm{CO}_{2}$, and nitrogen deposition on grassland diversity. Proc. Natl. Acad. Sci. U.S.A. 100, 7650-7654. doi: 10.1073/pnas.0932734100

Zimmermann, J., Hauck, M., Dulamsuren, C., and Leuschner, C. (2015). Climate warming-related growth decline affects Fagus sylvatica, but not other broadleaved tree species in Central European mixed forests. Ecosystems 18, 560-572. doi: $10.1007 /$ s10021-015-9849-x

Conflict of Interest Statement: The authors declare that the research was conducted in the absence of any commercial or financial relationships that could be construed as a potential conflict of interest.

Copyright (C) 2016 Dziedek, Härdtle, von Oheimb and Fichtner. This is an open-access article distributed under the terms of the Creative Commons Attribution License (CC BY). The use, distribution or reproduction in other forums is permitted, provided the original author(s) or licensor are credited and that the original publication in this journal is cited, in accordance with accepted academic practice. No use, distribution or reproduction is permitted which does not comply with these terms. 